\title{
Järjestöt kansalaisten edustajina hallinnonuudistuksessa?
}

\author{
Legitimointia, mahdollisuuksia ja odotuksia
}

\author{
Salla Pätilä \& Sanna Tuurnas
}

\begin{abstract}
In this paper, we study third sector organizations as representatives of citizens in the context of public sector reform. Our research focuses on third sector organizations as part of public service systems. Our aim is to examine how these organizations are able to filter citizen interests into public policy-making processes? The theoretical framework of this research is based on the concepts of participation, legitimacy and the developments of civil society in the era of participatory governance in Finland. We have interviewed representatives of third sector organizations operating in the field of social and health services. This set of interviews also forms the data of our study. Our key findings suggest that the social and health focused third sector organizations form a heterogenous group and they differ in their resources to represent citizens and their respective interest groups. Working together as allied groups in the public policy processes can, however, increase third sector organizations' possibilities to influence public sector reforms.
\end{abstract}

\section{JOHDANTO}

Osallistumisretoriikan yleistyminen julkishallinnossa liittyy uuden julkisen hallinnan paradigman esiin nousemiseen. Nykynäkemyksen mukaan yhteiskunnallisten ongelmien ratkaiseminen edellyttää laajaa osallistumista, joka lisää julkishallinnon toimijoiden käytettävissä olevaa tietopohjaa. Oletuksena tällöin on, että pelkkä julkishallinnon asiantuntijoiden osaaminen ei riitä moniselitteisiin yhteiskunnallisiin haasteisiin vastaamisessa. (ks. esim. Airaksinen 2009; Klijn \& Koppenjan 2012; Sotarauta 1998. Greve 2015; Pestoff 2012; Osborne 2010.) Julkisen hallinnon näkökulmasta kyseessä on tärkeä strateginen valinta: hallinnonuudistuksiin otetaan mukaan erilaisia toimijoita, jolloin niiden mukanaolo turvaa osaltaan uudistamisen legitimiteetin. (ks. esim. Mäkinen 2016, 99.) Keskiössä on päätöksenteon legitimiteetin säilyttäminen: kuinka perustella vähemmistön valitsemien edustajien tekemät päätökset niille kansalaisille, jotka eivät itse osallistu päätöksenteon prosessiin? (ks. esim. Valtiovarainministeriö 2017.)

Myös useita hallituskausia käynnissä oleva sosiaali- ja terveydenhuollon uudistus perustuu ideaan vahvasta osallistumisesta ja yhteistyöstä eri sektoreiden kesken. Tässä artikkelissa tarkastelemme erityisesti pääministeri Sipilän hallituksen maakunta- ja sote-uudistuksen valmisteluun $^{1}$ osallistuneiden järjestöjen näkökulmaa. Järjestöjen rooli on tunnustettu osana uudistuksen valmistelua sekä sosiaali- ja terveyspalvelujen suunnittelijoina ja tuottajina yhteistyössä kuntien kanssa (ks. HE 15/2017). Tutkimus on tehty Suomen kontekstissa. Tutkimuksen taustoittamiseksi onkin huomionarvioista nostaa esille suomalainen kuntien monipuolinen tehtäväkenttä julkisten palvelujen saralla, myös sosiaali- ja terveyspalveluissa. Tämä on yhdistettynä kuntien laajaan itsehallintoon pohjoismaiselle kuntamallille ominainen piirre. (Sjöblom 2011.). Monet tärkeät, ihmisten elämään vaikuttavat politiikkaprosessit toteutuvat siis paikallisella tasolla.

Kokonaisuudessaan kytkemme artikkelissamme hallinnon uudistamisen, uudistamisen legitimoinnin sekä kansalaisten osallistumisen ja niin kutsutun hallinnon 'osallistavan käänteen' yhteen. Tarkastelemme maaliskuussa 2019 päättynyttä hallinnonuudistusta erityisesti järjestöjen näkökulmasta. Artikkelissa kysymme, millä tavoin järjestöt voivat edustaa kansalaisia hallinnonuudistuksen kontekstissa. Kysymykseen vastataksemme tarkastelemme erityisesti järjestöjen näkemyksiä siitä, ketä ne edustavat sekä millaisia mahdollisuuksia niillä on toimia tämän 
kohdejoukon edustajina ja yhteiskunnallisina vaikuttajina. Johtopäätöksissä palaamme tarkastelemaan järjestöjen edustavuutta ja neuvotteluasemaa ja pohdimme tätä kautta hallinnonuudistustyön legitimoimista. Perusolettamuksemme on, että järjestöjen mukanaolo voi edistää hallinnonuudistuksen legitimointia julkisen hallinnon näkökulmasta, sillä valmisteluun osallistuvien määrän kasvaessa voidaan tavoitella paremmin perusteltuja päätöksiä ja vahvempaa legitimiteettiä. Tutkimus ei kuitenkaan pyri arvioimaan järjestöjen roolia ja asemaa juuri pääministeri Sipilän hallituksen valmistelemassa maakunta- ja soteuudistuksessa, vaan keskittyy tarkastelemaan tapaustutkimuksen kautta järjestöjen roolia osallistumishankkeissa yleisesti - valmisteltu uudistus näyttäytyy tässä tapauksessa kontekstina tutkimukselle.

Tutkimuksen aineisto on kerätty haastattelemalla pirkanmaalaisia maakunta- ja soteuudistustyöhön kiinnittyneitä sosiaali- ja terveysalan järjestöjen edustajia. Haastattelut on tehty keväällä $2018(\mathrm{~N}=13)$. Lisäksi tutkimuksessa on hyödynnetty marraskuussa 2017 järjestetyssä yleisötilaisuudessa kerättyä puolistrukturoitua lomakekyselyä, jonka $\mathrm{N}=47$.

\section{OSALLISTAVA KÄÄNNE JA HALLINNON UUDISTAMISEN LEGITIMOINTI}

Suomalaisessa kunnallishallinnossa hallinnan käsitteen ja uuden julkisen hallinnan paradigman vahvistuminen näkyvät sidosryhmäsuhteiden ja eri sektoreiden roolin korostumisena. Kunnissa pyritään yhä enemmän verkostomaiseen toimintatapaan ja laaja-alaiseen yhteistyöhön, jota tehdään muun muassa järjestöjen kanssa. Viime vuosikymmenien aikana suomalaista kunnallishallintoa on myös uudistettu tavoilla, joilla on pyritty vahvistamaan kuntalaisten ja sidosryhmien mahdollisuuksia vaikuttaa paikalliseen päätöksentekoon (mm. vapaakuntakokeilu alkaen vuonna 1989, kuntalain uudistaminen vuonna 2015). (ks. Haveri \& Majoinen, 2017.)

Julkishallinnon instituutiot ovat yleisesti avanneet suunnittelu- ja päätöksentekoprosessejaan 1980-luvulta alkaen, ja sidosryhmiä on kytketty osaksi prosesseja uusilla, monimuotoisemmilla tavoilla. Kansalaistoiminnan näkökulmasta osallistumisen voidaan katsoa helpottuneen, mutta toisaalta valta on hajaantuneempaa ja osallistumisen areenojen määrä on lisääntynyt. (Peltonen 2002, 168.)

Osallistamisella pyritään vahvistamaan hallintojärjestelmän legitimiteettiä. Legitimiteetti muuttaa vallan auktoriteetiksi ja tekee vallankäytöstä hyväksyttävää tilanteessa, jossa valta jakautuu asymmetrisesti. Vallankäyttö hyväksytään vapaaehtoisesti, sillä sen oletetaan noudattavan aiemmin sovittuja ja oikeutetuksi koettuja normeja. Valtaapitäville siis annetaan oikeus tehdä päätöksiä samalla sitoutuen päätöksenteon lopputuloksiin. (Schmitter 2001, 2-3.) Legitimiteetin rakentumista voidaan tarkastella syötteiden ja tuotteiden kautta. Hallintojärjestelmän syötepuolella legitimiteetin rakentumiseen vaikuttaa se, kuinka päätöksenteon prosessi rakentuu. Oleellista on se, ketkä päätöksentekoon osallistuvat sekä miten ja millä meriiteillä heidät on tehtävään valittu. Tuotospuolella taas arvioidaan sitä, kuinka hallintojärjestelmä on onnistunut sille määrättyjen tehtävien hoidossa. (Jäntti ym. 2017, 37-39.) Päätöksenteon prosessin legitimiteetin rakentumiseen vaikuttaa siis se, pidetäänkö prosessia sekä menetelmällisesti että sisällöllisesti hyväksyttävänä (Vartiainen 2011, 62

Legitiimeinä pidettyjen hallintojärjestelmien toimintaedellytykset ovat suotuisammat, ja niiden toiminnan transaktiokulut ovat pienemmät, sillä kansalaiset suhtautuvat lähtökohtaisesti luottavaisesti hallintojärjestelmän toimintaan ja sen tekemiin päätöksiin. (Härkönen ym. 2015, 189.) Kuten myöhemmin tarkennetaan, erityistä huomiota tulee kiinnittää legitimiteetin rakentumiseen, kun muodostetaan uusia tai muutetaan olemassa olevia hallintojärjestelmiä. Tämä on syy siihen, miksi myös makunta- ja soteuudistuksessa valmisteltu makuntatasoinen hallintojärjestelmä tulisi rakentaa niin, että sitä pidetään legitiiminä jo rakennusvaiheessa (syötepuoli).

\section{LEGITIMITEETIN LÄHTEET}

Klassisen weberiläisen jäsennyksen mukaan legitimiteetti kumpuaa perinteestä, legaalis-byrokraattisesta järjestelmästä ja karismasta. Jos legitimiteetin muodostumista tarkastellaan puhtaasti edustukselliseen demokratiaan perustuvissa hallintojärjestelmissä, Weberin näkemys 
legitimiteetin lähteistä on sovellettavissa myös nykyajan hallintojärjestelmiin (Härkönen ym. 2015, 190). Legitimiteetti perustuu edustuksellisessa demokratiakäsityksessä ennalta määrättyyn ja luotettavaan äänestysmenettelyyn sekä äänten enemmistön saavuttamiseen. Vaaleilla valituille edustajille on annettu mandaatti tehdä päätöksiä kansalaisten puolesta. Tällöin legitimiteetti kumpuaa valittujen edustajien tilivelvollisuudesta äänestäjiään kohtaan. (Klijn \& Edelenbos 2013, 632-635.)

Osallistuvan ja deliberatiivisen demokratiakäsityksen mukaan hallinnon legitimiteetin lähteeksi ei riitä vaaleilla valittuja edustajia sitova tilivelvollisuus (Dryzek 2005, 233). Hallintojärjestelmän legitimiteetin rakentuminen perustuu toimivan edustuksellisen järjestelmän lisäksi kansalaisten ja sidosryhmien aktiiviseen osallistumiseen ja monipuolisiin osallistumisen menetelmiin (Michels 2011, 277-279). Jos legitimiteetin lähteenä pidetään sidosryhmien äänen kuulumista, korostuu sidosryhmien aktiivinen ja aito osallistuminen konkreettisiin päätöksiin ja prosesseihin. Jos legitimiteetin nähdään muodostuvan deliberaation myötä, tarkastelun painopiste on siinä tavassa, miten sidosryhmien ja päätöksentekijöiden välinen vuorovaikutus on järjestetty: täyttyvätkö deliberaatiolle asetetut ehdot, eli tiedon avoin jakaminen ja erilaisten näkemysten ja vaihtoehtojen vertailu. (Klijn \& Edelenbos 2013, 635.)

Muuttuvan demokratiakäsityksen lisäksi hallintojärjestelmät, jotka toimivat edustuksellisen demokratian periaatteiden lisäksi verkostoissa, haastavat perinteistä legitimiteetin määritelmää. (Härkönen ym. 2015, 190.) Koska kansalaisyhteiskunnan, liike-elämän ja muiden sidosryhmien mukaan ottaminen ja sitouttaminen on välttämätöntä sektorien rajat ylittävien ongelmien ratkaisemiseksi, verkostoissa poliittiseen päätöksentekoon eivät osallistu vain edustuksellisen demokratian instituutioiden toimijat. (ks. esim. Klijn \& Skelcher 2007.) Tämän takia on oleellista pohtia, kuinka päätöksentekoa verkostoissa legitimoidaan. Jos keskitytään legitimiteetin muodostumiseen vain edustuksellisen demokratian näkökulmasta eli siihen, että legitimiteetti kumpuaa valittujen edustajien tekemistä päätöksistä, verkostojen toimintalogiikan legitimiteetti voidaan perustellusti kyseenalaistaa. (Klijn \& Edelenbos 2013, 631.)
Klijn ja Edelenbos (em.) tarkastelevat tutkimuksessaan, kuinka eri legitimiteetin lähteet vaikuttavat verkostojen toimivuuteen. Tapauksissa, joissa vastaajat katsoivat sidosryhmien äänten kuuluneen ja deliberaation toteutuneen, verkostotyöskentely tuotti onnistuneempia lopputuloksia. Edustuksellisten elinten tilivelvollisuuden toteutuminen ei edesauttanut merkittävästi hyviin lopputuloksiin pääsemistä. Selitystä tälle kirjoittajat etsivät verkostojen luonteesta ja siitä mitä on niiden toiminnan onnistumiselle välttämätöntä: toimijoiden tuominen yhteen, heidän intressiensä yhdistäminen sekä resurssien ja tiedon vaihto. (Klijn \& Edelenbos 2013, 644-646.) Toisin sanoen verkostojen työskentelyn kannalta on oleellista, että huomiota kiinnitetään siihen, kuinka sidosryhmien ääni kuuluu prosessissa ja päätöksenteossa. Lisäksi merkityksellistä on sidosryhmien ja päätöksentekijöiden välisen vuorovaikutuksen laatu: onko keskustelulle ja erilaisten näkemysten esittämiselle todellisia mahdollisuuksia?

\section{LEGITIMITEETTI JA HALLINTO- JÄRJESTELMÄN MUUTOS}

Uuden hallintojärjestelmän rakentuessa huomio kiinnittyy legitimiteetin kannalta ensin syötepuolen ratkaisuihin, eli siihen minkälaiseksi päätöksenteon prosessi rakentuu. Edustuksellisen osallistumisen käytännöt ovat yksi elementeistä, joiden avulla legitimiteettiä rakennetaan uuden hallintojärjestelmän alkuvaiheessa. Monipuolisten osallistumis- ja vaikutusmahdollisuuksien turvaaminen kuitenkin ylläpitää legitimiteettiä myös hallintojärjestelmän perustamisvaiheen jälkeen. (Jäntti ym. 2017, 53.) Jatkuvuus on oleellista, sillä täysin uuden hallintorakenteen legitimiteetti muotoutuu hitaasti ja on luonteeltaan dynaamista (Härkönen ym. 2015, 191).

Osallistumis- ja vaikuttamismahdollisuuksien vahvistaminen ei kuitenkaan aina istu olemassa olevaan hallintojärjestelmään, ja erilaisten tavoitteiden yhteensovittaminen voi synnyttää institutionaalista jännitettä. Osallistuminen toteutuu usein projektimaisena työskentelynä, joka synnyttää väliaikaisen institutionaalisen rakenteen. ${ }^{2}$ Se ei välttämättä sovi yhteen olemassa olevan hallintojärjestelmän kanssa, jonka toimintalogiikka perustuu edustuksellisen demokratian vertikaaliseen vastuun ja vallan jakoon. (Edelenbos 
2005, 113-116.) Oleelliseksi kysymykseksi muodostuu, mitä osallistumiselle tavoitellaan: onko kansalaisten (ja kansalaisyhteiskunnan) osallistumisen tarkoitus muuttaa vallitsevia instituutioita, vai kytketäänkö osallistuminen osaksi olemassa olevia instituutioita, jolloin osallistumista käytetään julkishallinnon instituutioiden "virittämiseen" ja tehokkaamman hallinnan kehittämiseen (ks. esim. Salminen ym. 2016).

Toisaalta on hyvä muistaa, ettei verkostotyöskentely todellisuudessa aina toteuta sille kirjallisuudessa asetettuja, idealistisinakin pidettäviä määreitä kuten osallistujien monimuotoisuutta tai tasaveroisuutta (ks. esim. Innes \& Booher 2010). Julkishallinnon organisaatiot työskentelevät mielellään sellaisten toimijoiden kanssa, joiden toimintatavat ovat mahdollisimman lähellä niiden omia toimintatapoja. Pääseminen mukaan erilaisiin hallinnan verkostoihin voi riippua siitä, miten hyvin järjestöt pystyvät vastaamaan verkoston toisten jäsenten tarpeisiin. Tämä johtaa helposti järjestöjen korostuneeseen rooliin asiantuntijoina. (Peltonen 2002, 172; Giugni \& Passy 1998.) Osallistumisen mahdollisuudet ovatkin ehdollisia niille rakenteellisille ratkaisuille, jotka syötevaiheessa rakennetaan: ketkä pääsevät ääneen ja miten. (Jäntti ym. 2017, 52-54.). Tähän kysymykseen emme voi tyhjentävästi vastata tutkimuksemme rajausten johdosta. Voimme kuitenkin nostaa esille tärkeitä huomioita järjestöjen roolista ja mahdollisuuksista edustaa kansalaisyhteiskuntaa hallinnon uudistuksen rakenteissa. Seuraavassa luvussa käsittelemmekin tarkemmin erityisesti järjestöjen roolia osana kansalaisyhteiskuntaa ja laajemmin koko yhteiskuntaa.

\section{JÄRJESTÖT OSANA KANSALAIS- YHTEISKUNTAA JA YHTEISKUNTAA}

Tutkimuksemme kohteen, järjestöjen, voidaan katsoa edustavan kansalaisyhteiskuntaa, vaikka ne voidaan nähdä myös palveluntuottajaroolissa valtion ja yksityisen sektorin rinnalla (ks. esim. Brandsen, Trommel \& Verschuere 2017; Evers 2005; Evers \& Laville 2004), ja vaikka kansalaisyhteiskunta tarkoittaa myös ylipäätään vapaata kansalaistoimintaa, ammattiyhdistyksien ja poliittisten puolueiden toimintaa, osuuskuntia ja säätiöitä. Harju (2010, 14-15) tiivistääkin kansalaisyhteiskunnan erityisen olemuksen vertaa- malla sitä muihin sektoreihin, yksityiseen ja julkiseen: "sillä on erilaiset arvot, päämäärät, tavat toimia ja organisoitua ja erilainen logiikka [....] Kansalaisyhteiskunnassa ihmiset ovat sekä toimijoita että samalla toiminnan kohteita". Tähän tiivistykseen myös järjestöt erilaisine toimintalogiikoineen sopinevat usein hyvin, vaikka osa järjestö toimiikin hyvin yritysmäisesti tai julkisen palveluorganisaation tavoin. Järjestöjen erittäin heterogeenisen roolin tunnistaen ja tunnustaen katsomme järjestöjen kuitenkin lähtökohtaisesti edustavan kansalaisyhteiskuntaa.

Suomessa järjestöt kansalaisyhteiskunnan osana ovat rakentaneet hyvinvointivaltiota yhdessä kuntien ja valtion kanssa, ja niillä on ollut, ja edelleen on, tärkeä rooli sosiaali-ja terveyspalvelujen tuottajana ja uudistajana. Järjestöt ja yhteisöt ovat laittaneet alulle monia sittemmin julkisiksi palveluiksi muuttuneita, suomalaiseen hyvinvointivaltioon olennaisesti kuuluvia toimia ja asioita, kuten neuvolatoiminnan, äitiyspakkauksen ja sosiaalisen asuntotuotannon (Anttonen ym. 2012; Haveri 2012; SOSTE 2014).

Viimeisimmän vuosikymmenen aikana järjestökentän idea on muuttunut erityisesti niiden ydintehtävien osalta: järjestöt toimivat entistä ammattimaisemmin palvelutuottajina. Järjestöissä tehdään myös yhä enemmän palkkatyötä. Samaan aikaan kansalaisyhteiskunnan edunvalvontaroolin voidaan katsoa heikentyneen: erityisesti poliittisten järjestöjen määrä on vähentynyt (Julkunen 2007; Siisiäinen \& Kankainen 2009). Tällainen kehitys on vaikuttanut järjestöjen perustavanlaatuiseen toimintalogiikkaan: toimintaa ohjaa aatteellisuuden sijasta ammattilaisuus ja ammatilliset normit.

Järjestöjen toimintaa on muuttanut myös markkinoistamiskehitys, joka voidaan nähdä jatkumona 1990-luvulla alkunsa saaneesta New Public Management -johtamisopeista (myöhemmin NPM) (ks. esim. Rantamäki 2016). Myös niin kutsuttu vastuuttamiskehitys on osa laajempaa, Iso-Britannian sosiaalipolitiikasta ideoivaa kehitystä. Kyse on "tehdään vähemmän enemmällä" -ideologiasta, jossa hallintoa vähennetään, korvaten sen toiminnat kansalaisten ja kansalaisyhteiskunnan panoksella nk. rohkaisupolitiikkaa hyödyntäen. (Koskiaho 2015, 54.) Samaa kehitystä voimme havaita myös laajemmassa, kansalaisvälisessä kontekstissa: kansalaisyhteiskunnalle ladataan paljon 
odotuksia ihmisten hyvinvoinnin ylläpitämisestä (ks. Brandsen, Trommel \& Verschuere 2017; Peeters 2013; Pestoff 2012). ${ }^{3}$

Järjestöjä kutsutaan myös hallinnon kumppaniksi vahvistamaan aktiivista kansalaisuutta ja vapaaehtoistyötä. Pahimmillaan vastuuttaminen voi tarkoittaa sitä (erityisesti kuntien ja järjestöjen rajapintoja tarkasteltaessa), että julkista rahoitusta vähennetään kuitenkin odottaen, että järjestöt itse hankkivat toiminnalleen rahoitusta esimerkiksi varainhankinnan kautta (Koskiaho 2015). Samaan tapaan SOSTE:n Järjestöbarometrissa (2016) nähdään riskinä, että kuntien kiristyvän talouden sekä ja uudistuvien sote-rakenteiden puristuksessa julkisten palvelujen ja kansalaistoiminnan rajat hämärtyvät.

Ylipäätään 2010-luku, sekä erityisesti käsillä oleva sosiaali- ja terveyspalvelujen uudistaminen - maakuntauudistusta unohtamatta - on tuonut järjestöille uusia, kahdensuuntaisia ja jopa ristiriitaisia odotuksia ja paineita. Toisaalta sosiaali- ja terveyspalvelujen markkinoistamisen uudistus tuo paineita järjestöille kehittää edelleen palveluntuotantoa, miettiä asiakasarvoa ja luoda toiminnalle standardeja. Tämä kehitystrendi koskettaa luonnollisesti erityisesti niitä järjestöjä, jotka toimivat jo nyt palveluntuotannon piirissä. Toisaalta kaivataan myös vahvaa kansalaisyhteiskuntaa, jonka toiminnan ytimessä on aktiivinen kansalaisuus, vapaaehtoisuus ja yhteisöllisyyden vahvistaminen (ks. Brandsen, Trommels \& Verschuere 2017; Fotaki 2011; Peeters 2013). Koskiaho (2015) painottaakin, että tarvitaan selkeitä sopimuksia siitä, millainen rooli kansalaisyhteiskunnalla ja järjestöillä on suomalaisessa yhteiskunnassa. Myös järjestöt itse toivovat kuntiin järjestöstrategioita (ks. esim. Peltosalmi jne. 2012). Tämä keskustelu onkin erityisen ajankohtainen. Esimerkiksi Särkelä (2016) painottaa, että tämänhetkisessä hallinnon uudistustyössä ei riittävästi oteta tätä yleishyödyllistä osaa järjestöjen toiminnasta huomioon.

Kansalaisyhteiskuntapolitiikan neuvottelukunnan, Kansalaisareena ry:n ja Suomen kuntaliiton tekemässä kyselytutkimuksessa (2015) todetaan, että kunnat tarvitsevat järjestöjen tuottamia palveluita: vain neljä prosenttia kyselyyn vastanneista uskoi, että kunta pystyy itse vastaamaan palvelujen tuottamisesta. Vapaaehtoisten toimintaa ja panosta kaivataan etenkin täydentämään kuntien omaa palvelutuotantoa. Voidaan siis todeta, että järjestöt ja yhteisöt ovat kunnille merkityksellisiä ja elintärkeitä kumppaneita.

Kyselytutkimusraportissa kuitenkin myös - paradoksaalisesti - todetaan, etteivät kunnat todennäköisesti tule merkittävästi lisäämään järjestöjen taloudellista tukea. Tätä taustaa vasten voidaan pohtia erityisesti kuntien ja järjestöjen kumppanuutta suhteessa kansalaisyhteiskunnan toimintaedellytyksiin ja järjestöjen autonomiaan. Niukoista resursseista kilpaileminen ei välttämättä edistä tasapuolista kumppanuutta ja neuvotteluasemaa järjestöille. Tätä huomiota tukee Suomen Sosiaali- ja terveys ry:n uusimman järjestöbarometrin ennakkotieto, jonka mukaan järjestöistä 10 prosenttia oli tyytymättömiä autonomiaan vuonna 2016, kun vuonna 2018 luku oli 23 prosenttia. Kansalaistoiminnan ja julkisen vallan suhde onkin tärkeä ja klassinen sosiaalityön teema, jota on syytä edelleen tutkia (Smolej 2017). Tämä suhde koskettaa laajemmin yhteiskuntapolitiikan ydinteemoja hegeliläisestä yhteiskuntasopimuksesta ja Adam Smithin taloudellisen liberalismin opeista edelleen Habermasin teorioihin julkisesta tilasta (ks. Kansalaisyhteiskunta 2018; Koskiaho 2015). Tällä huomiolla voimme osaltaan myös perustella artikkelimme näkökulmaa myös hallinnonuudistuksen kontekstissa.

Lopuksi on tärkeää painottaa - huolimatta tämän artikkelin kontekstoimisesta maakuntaja sote-uudistukseen - että järjestökentän muutoksen ajurit ovat syvemmällä kuin käsillä olevassa hallinnon uudistamisessa. Edellä käytyä keskustelua yhteen vetäen voidaan todeta, ettei järjestöjen, yhdistysten ja yhteisöjen, siis kansalaisyhteiskunnan ydintoimijoiden, taloudellinen riippuvuus kunnista yhdistettynä yleisen edunvalvontaroolin heikkenemiseen välttämättä tue ajatusta siitä, että järjestöt voivat edustaa kansalaisia ja valvoa kansalaisten etujen toteutumista tasapuolisesti. Toisaalta parhaimmillaan järjestöt voivat toimia välittäjäorganisaatioina kansalaisten ja julkisen vallan välillä. Kuten Harju $(2010,113)$ painottaa pohdinnassaan suomalaisen demokratian kriisistä ja parantamisen keinoista: "Kansalaisjärjestöt voivat tarjota yhden uuden ratkaisun toimimalla välittävänä aktorina kehittyvässä osallistuvassa demokratiassa. Suuri kysymys kuuluu, ovatko järjestötoimijat 
kiinnostuneita tästä roolista [...]?” Tähän kysymykseen tutkimuksemme pyrkii osaltaan vastaamaan.

\section{TUTKIMUKSEN AINEISTO, METODOLOGIA JA TUTKIMUKSEN RAJOITTEET}

Tutkimuksen ensisijainen aineisto on kerätty haastattelemalla pirkanmaalaisia maakunta- ja soteuudistustyössä mukana olleita sosiaali- ja terveysalan järjestöjen edustajia. Haastateltavat on valittu sen perusteella, että heillä on asemansa puolesta luonnollista ja syvällistä tietämystä järjestöjen roolista ja asemasta yhteiskunnassa (ks. Jupp 2011). Tutkimuksen kohdentaminen näihin järjestöihin nousi kirjoittajien havainnoista, jotka koskivat järjestöjen asemaa ja roolia makunta- ja soteuudistuksessa. Toinen kirjoittajista on myös osallistunut osallisuutta koskevaan maakunta-soteuudistuksen valmisteluryhmään, joka on tämän tutkimuksen kannalta olennainen tutkimuksen kohde. Riskinä voi olla, että tutkijan omat kokemukset vaikuttavat tutkimukseen vääristävällä tavalla - tämän olemme huomioineet tutkimusprosessissa tutkijatriangulaation avulla.

Haastattelut on toteutettu teemahaastatteluin. Teemoja olivat 1) Järjestön toiminta ja agenda 2) Maakunta-ja soteuudistuksen valmistelutyö yhteistyön alustana 3) Oman järjestön rooli palvelujärjestelmässä ja yhteistyö eri toimijoiden kanssa 4) Odotukset ja odotuksiin vastaaminen maakunta- ja soteuudistuksessa 5) Tulevaisuus. Haastattelut ovat kestoltaan noin 60 minuutin mittaisia. Haastattelut on tehty keväällä 2018 $(\mathrm{N}=13)$ Haastattelut on nauhoitettu ja litteroitu. Lisäksi tutkimuksessa on hyödynnetty uudistusorganisaation marraskuussa 2017 järjestämässä yleisötilaisuudessa kerättyä puolistrukturoitua lomakekyselyä, jossa $\mathrm{N}=47$. Kummatkin kirjoittajat olivat mukana tilaisuuden järjestämisessä sekä aineiston keräämisessä.

Tutkimus on luonteeltaan eksploratiivinen tapaustutkimus, jolloin tutkimusprosessi on alkanut aineiston keräämisellä. Tutkimusprosessi on siis suunniteltu aineistolähtöisesti, ja konseptuaalinen ja teoreettinen tutkimuskehys on rakennettu aineistolähtöisten havaintojen perusteella (ks. Streb 2010; Yin 2003). Toisaalta tutkimus voidaan määritellä myös Staken (1995) tyypittelyn mukaisesti instrumentaaliseksi tapaustutki- mukseksi ${ }^{4}$. Näin siksi, että tutkimuksen tapaus ei ole tutkimuksen varsinainen kohde, vaan tapausta käytetään välineellisesti kuvaamaan jotain muuta kuin tapausta itseään. Tapaus tässä tutkimuksessa on muodostunut Pirkanmaan maakunta- ja soteuudistuksen valmistelutyön prosessista. Tutkimuksessa ei kuitenkaan keskitytä kuvaamaan tai analysoimaan tätä kyseistä prosessia sinänsä, vaan sitä käytetään välillisesti hyödyksi tutkittaessa, millä tavoin järjestöt voivat edustaa kansalaisyhteiskuntaa hallinnonuudistuksen kontekstissa. Tapaustutkimuksen luonteen mukaisesti tutkimus keskittyy tiettyyn kontekstiin (ks. Flyvberg 2006), joka tässä yhteydessä on hallinnonuudistus eli maakunta- ja soteuudistus. Käytännöllisemmällä tasolla kontekstina toimii Pirkanmaa.

Analyysissä tulkitsemme informanttien tulkintoja. Aineisto on alustavasti analysoitu aineistolähtöisen sisällönanalyysin keinoin, joskaan puhtaasta aineistolähtöisyydestä ei tässä tutkimuksessa ole kyse. Erityisesti osallistumisen näkökulma on kantanut tutkimusprosessia alusta asti, joskin tarkempi näkökulma on tutkimuksen aikana muokkautunut. Aineiston alustavan järjestelyn ja kategorisoinnin perusteella mukaan on tullut teoriasidonnaisuutta. Legitimaationäkökulma toimii tästä erityisesti esimerkkinä. Näin tutkimus noudattaa melko tyypillistä laadullisen sisällönaineiston logiikkaa, jolloin analysointiprosessi alkaa tutkimuskysymyksen määrittelystä ja jatkuu asteittaisella (tässä tapauksessa induktiivisten) kategorioiden ja tulkintakehyksen rakentamisella sekä niiden uudelleenmuotoilulla siirtyen siitä lopullisten kategorioiden määrittelyn kautta tutkimustulosten tulkintaan ja esittelyyn (Gläser \& Laudel 2013; Schreier 2014).

Tutkimukseen liittyy myös rajoitteita. Ensinnäkin, tutkimuksen laadullisen luonteen vuoksi tutkimuksesta ei voida vetää yleistettäviä johtopäätöksiä. Tutkimuksen tarkoituksena onkin ymmärtää ja oppia tuloksista ja edesauttaa näin teorioiden kehittämistä (Flyvberg 2006). Yksityiskohtaisemmalla tasolla tutkimuksessa on mukana pirkanmaalaisittainkin vain rajattu joukko järjestöjä, jotka ovat kaikki olleet mukana jollain tavalla uudistustyössä. Tämä voi vaikuttaa tutkimuksen tuloksiin, jotka saattaisivat näyttää toisenlaisilta, jos mukana olisi myös järjestöjä, jotka ovat syystä tai toisesta olleet uudis- 
tustyöstä täysin irrallaan. Lisäksi kustakin järjestöstä on haastateltu vain yhtä henkilöä: tämä voi vaikuttaa tutkimuksen tuloksiin, sillä erityisesti suurissa järjestöissä johtavien toimijoiden näkemykset osallisuuden toteutumisesta voivat erota niin sanottujen rivijäsenten näkemyksistä. Lopuksi, kuten alla toteamme, järjestöjen heterogeenisyys voidaan nähdä tutkimuksen kannalta ongelmallisena: millaisen joukon haastateltavat loppujen lopuksi muodostavat? Tämän seikan olemme huomioineet ja tuoneet esille analyysissä. Lisäksi, kuten tutkimustuloksista käy ilmi, haastateltavien edustamat järjestöt ovat yhtä aikaa erilaisia ja samanlaisia. Tämä voidaan nähdä aineistoa ja analyysia, ja laajemmin koko tutkimusta, rikastuttavana seikkana.

\section{TUTKIMUKSEN TULOKSET}

\section{Järjestökentän heterogeenisyys ja vaikutusmahdollisuudet}

Järjestökentän heterogeenisyys on ilmeistä tarkasteltaessa tutkimuksen aineistoa. Osa tutkimukseen valikoiduista järjestöistä toimi hyvin paikallisesti (kaupunginosatoiminta), muutama järjestöistä toimi koko Pirkanmaan maakunnan alueella, ja moni järjestöistä oli osa laajempaa, valtakunnallista yhdistystä, jolla on paikallista toimintaa Tampereen alueelle. Myös järjestöjen kokoluokka vaihteli kymmenien tuhansien jäsenten valtakunnallisesta yhdistyksestä järjestöihin, joiden toiminta pyöri muutaman henkilön voimin. Lisäksi järjestöjen ammattimaisuuden asteessa oli eroja. Osalla oli palkattuja ja koulutettuja ammattilaisia, yksi tutkimuksen järjestöistä toimi kokonaisuudessaan vapaaehtoispohjalta. Ammattimaisuuden aste vaikutti erityisesti tiedonkulkuun: isoissa järjestöissä kattojärjestö välitti tietoa maakunta- ja soteuudistuksen etenemisestä paikallistasolle. Pienillä järjestöillä ei ole ollut mahdollisuuksia kerätä tietoa valtakunnan tasolla ja stilisoida sitä valmiiksi pureskeltuun muotoon. Järjestöt olivatkin erilaisessa asemassa perustuen niiden kokoon, resursseihin, ammattiosaamiseen sekä mahdollisuuksiin päästä uudistuksen liittyvän tiedon "alkulähteelle".

Järjestöjen toimintalogiikat olivat myös erilaista. Muutama tutkimuksen järjestöistä keskittyi pelkkään kansalaisvaikuttamiseen ja edun- valvontaan, mutta suurin osa järjestöistä tuotti kansalaisvaikuttamisen lisäksi sosiaali- ja terveysalan palveluja. Lisäksi järjestöjen rahoituspohja vaihteli. Sosiaali- ja terveysjärjestöjen avustuskeskus (myöhemmin STEA) ja Tampereen kaupunki tukivat useimpia tutkimuksen järjestöjä avustuksilla. ${ }^{5}$ Järjestöt saivat varoja myös omien palveluidensa myynnistä, mikä oli osalle järjestöistä välttämätöntä toiminnan jatkuvuuden turvaamiseksi: myyntivoitto voitiin käyttää järjestön toiminnan kehittämiseen ja muuhun projektien ulkopuoliseen toimintaan toisin kuin ulkopuolelta tuleva, projektikohtainen rahoitus.

Järjestökentän moninaisuus oli joidenkin haastateltavien mukaan johtanut siihen, että julkisen sektorin päättäjät eivät tunne järjestöjen toimintaa:

"-- on hyvin monentapasia ajatuksia siitä mitä järjestötoiminta on. Ja helpostihan se, ja on hyvin monenlaisia järjestöjäkin täällä Pirkanmaalla, niin helposti se ajatellaan vähän semmoseks puuhailuks, se järjestötoiminta. Se nähdään positiivisena asiana, mut sitä et mitä se on ja mitä sen mahdollisuudet on ja mitä kaikkea se pitää sisällään, niin semmosta kokonaiskuvaa ei oo." (J3.)

Päätöksentekijät kunta- ja maakuntatasolla eivät aina nähneet järjestöjen toimintamahdollisuuksia ja potentiaalia, elleivät järjestöjen edustajat itse niitä tuoneet aktiivisesti esiin. Kuten seuraavassa luvussa todetaan, mahdollisuudet oman toiminnan esiin nostamiseen riippuvatkin järjestöjen henkilö- ja aikaresursseista sekä olemassa olevista verkostoista.

\section{Ketä järjestöt edustavat?}

Monet järjestöjen edustajista katsoivat edustavansa omaa kohderyhmäänsä pyrkiessään vaikuttamaan uudistuviin sosiaali- ja terveyspalvelujen rakenteisiin. Edunvalvonta ja erityisesti oman kohderyhmän, kuten nuorten tai vammaisten, äänen esille tuominen julkisessa keskustelussa ja päätöksenteossa oli haastateltavien mielestä toiminnan ydinasia - tämä pyrkimys yhdisti järjestöjen moninaista joukkoa. Osa haastatelluista puhui järjestöistä myös yleisesti kansalaisyhteiskunnan edustajana ja julkisen sektorin toiminnan "laadunvalvojana". Moni 
näki järjestöjen toimivan myös jonkinlaisena välikätenä, "sanansaattajana", julkisen sektorin ja kansalaisten (ja asiakkaiden) välillä. Järjestöjen välillä oli kuitenkin eroja: toisilla järjestöillä isossa roolissa olivat oman kohderyhmän erityistarpeisiin tuotetut palvelut. Haastatellut järjestöjen edustajat perustelivat rooliaan palveluntuottajana erityisosaamisella, jota järjestöissä koettiin luonnostaan olevan.

Kiinnostavaa tämän artikkelin kannalta onkin se, kenen asialla järjestöt kokivat olevansa osallistuessaan maakunta- ja sote-uudistuksen valmisteluun. Suurin osa haastatelluista katsoi, että järjestöt - oman kohderyhmänsä lisäksi - edustavat laajemmin koko kolmatta sektoria. Eroista huolimatta haastateltavat kokivat, että järjestöjä sitoo yhteen toiminnan samankaltaisuus. Lisäksi uudistuksen aiheuttaman epävarmuuden uskottiin tuovan toimijoita yhteen: hallinnonuudistuksen myötä järjestöjen tulevaisuuden koettiin olevan vaakalaudalla, minkä takia järjestöt tavoittelivat "yhtenäistä rintamaa" ja pyrkivät näin vahvistamaan koko järjestökentän roolia päätöksenteossa. Haastateltavat olivat kuitenkin erimielisiä sen suhteen, pystyivätkö uudistustyössä aktiivisimmin mukana olevat järjestöt edustamaan koko järjestökenttää. Muutama haastateltavista kritisoi sitä, että uudistustyön valmisteluun valittiin vain rajattu joukko järjestökentän edustajia: " -- vaikea kuvitella, että yksi ihminen pystyy puhumaan kaikkien järjestöjen puolesta.” Osa kaipasikin järjestäytyneempää ja edustuksellista rakennetta, jonka kautta järjestöjen yhteinen kanta muodostettaisiin.

Myös sen, tekivätkö järjestöt vapaaehtoistyötä, kansalaisvaikuttamista vai palvelutuotantoa, koettiin vaikuttavan järjestöjen mahdollisuuksiin vaikuttaa hallinnonuudistukseen. Erään haastateltavan mukaan ammattimaisemmin palveluja tuottavat järjestöt ovat paremmassa asemassa hallinnonuudistuksessa, sillä niiden yhteys tuleviin makuntiin olisi selkeämpi verrattuna vapaaehtoistoimintaan ja vertaistukeen keskittyviin järjestöihin.

Järjestötoimijoiden asema vapaan kansalaisosallistumisen edistäjänä uudistuksessa ei myöskään ollut ongelmaton. Kuten haastatteluista kävi ilmi, järjestöt ovat tottuneet erityisesti järjestövaikuttamisen kysymyksiin. Vapaan kansalaisosallistumisen edistäminen kuitenkin koettiin tärkeäksi tehtäväksi, vain työvälineet ja toimintatavat puuttuvat:

"-- meillä on ollu haasteita saada sitä tavallista kansalaista siihen osallistettua kuitenkaan sillä tasolla kuin voisi olla hyvä, mikä on tietysti paljon laajempikin haaste mutta siihen ei oo ehkä semmosia keinoja löytyny." (J9.)

Järjestöjen edustajia yhdisti huoli epävarmasta tulevaisuudesta. Vaikka pirkanmaalaiset järjestöt olivat osallistuneet uudistuksen valmisteluun, suunnitellun hallintomallin rakenteet eivät olleet selvillä. " -- tää on tämmönen sumuinen meri, missä pitäs navigoida, mutta ei nää mihin me ollaan menos. Kukaan ei tiä mihin ollaan menossa mut johonkin ollaan menossa, niin se aiheuttaa aina välillä vähän semmosta, että selkeä näky puuttuu." (J3.) Erityisesti järjestöjen edustajien kommenteissa toistui huoli epäselvästä jaosta hyvinvoinnin ja terveyden edistämisen sekä sosiaali- ja terveyspalvelujen välillä ja jaon vaikutuksista järjestöjen rahoituspohjaan. Herääkin kysymys, kaventaako hallinnonuudistus järjestöjen mahdollisuuksia edustaa kansalaisyhteiskuntaa ja ylipäätään toimia: epävarmuuden ilmapiirissä epäkohtia ei ole helppo nostaa esille.

\section{Järjestöjen vaikutusmahdollisuudet hallinnonuudistuksessa ja sen valmistelussa}

Haastatellut järjestöjen edustajat olivat huolissaan siitä, miten maakunta- ja soteuudistus vaikuttaa järjestöjen kuntakumppanuuksiin ja sitä kautta järjestöjen vaikutusmahdollisuuksiin. Henkilökohtaisia, kahdenvälisiä suhteita pidettiin merkityksellisinä järjestön ja kuntasektorin väliselle yhteistyölle, sillä pitkään jatkuneen yhteistyön myötä järjestön toiminta oli tullut kunnan työntekijälle tutuksi ja sitä oli opittu arvostamaan. Myös lomakekyselyyn vastanneet pohtivat järjestöjen tulevaisuutta tilanteessa, jossa julkisen sektorin toiminta järjestetään uudelleen kunta- ja aluetasolla. Vastauksissa toistui pelko siitä, että päätöksenteon karatessa kauemmas tulisi julkissektorin toimijoiden yhteys järjestöjen paikalliseen toimintaan katoamaan. Tämä vaikuttaisi negatiivisesti järjestöjen vaikuttamismahdollisuuksiin. 
Moni haastatelluista järjestöedustajista teki vaikuttamistyötä ja edunvalvontaa sekä valtakunnallisella että paikallisella tasolla. Paikallinen vaikuttamistyö ja edunvalvonta nähtiin tärkeänä, sillä paikallisyhdistysten jäsenet tuntevat parhaiten oman alueensa erityiskysymykset ja ne julkisen sektorin toimijat, joihin vaikuttamista tulisi kohdistaa. Paikallistason järjestötoimijat kuitenkin kokivat vaikuttamistyön ja edunvalvonnan vaikeaksi ja etäiseksi muun muassa koetun asiantuntijuuden ja tiedon puutteen takia:

" -- jos ajattelee että sulla on siellä kunnan edustajia, viranhaltijoita ja sitten maakunnasta mahdollisesti ja mistä nyt voikaan olla sitten niitä muita ryhmäläisiä ja sit jos sä yksin siellä yrität puhua sillä suulla että järjestötkin on olemassa ja me tehdään tällasta työtä -- ja nää asiat on tärkeitä ja tavallaan tuoda sinne sitä sellasta, tavallisen ihmisen, kuluttajan, asiakkaan, kuntalaisen ääntä niin, ehkä tulis semmonen tunne että helposti jää jalkoihin, tai sit pitäis olla tosi voimakas persoona ja hyvin perustella -- ." (J5.)

Kumppanuussuhteiden ja paikallisen vaikuttamisen lisäksi haastatellut järjestöedustajat kiinnittivät huomiota siihen, miten maakunta- ja sotevalmistelutyöhön osallistuminen oli Pirkanmaalla järjestetty. Osa järjestöjen edustajista kyseenalaisti sen, miten järjestöjen osallistuminen uudistuksen valmisteluun lopulta näkyi päätöksenteossa:

"-- et se ei oo vaan jutustelua ja sitten jotain diaesityksiä vaan siis oikeesti päätöksiä ja sillä tavalla mä aattelen jotenkin et se on jotain konkreettista, et se ei oo mitään poliittista kivaa lässytystä että tämmöstä, kiva kun osallistutte, vaan että siinä oikeesti sitten on joku vaikutuskin --." (J7.)

Lisäksi moni haastateltavista olisi toivonut osallistumisen kautta tuotettujen syötteiden ohjanneen virkamiesten työtä konkreettisemmalla tavalla: yleisen tason ehdotelmien sijaan toivottiin selkeämpiä ja sitovampia kannanottoja. Liiallinen tulkinnanvaraisuus esityksissä ei vakuuttanut haastateltavia, jotka olivat odottaneet pääsevänsä ohjaamaan virkamiesten työtä tai ainakin asettamaan ne raamit, joiden puitteis- sa virkamiehet työtään tekisivät. Oman työpanoksen ja odotusten sekä lopputulosten välinen ristiriita sai jotkut järjestöedustajista pohtimaan kriittisesti motiiveja osallistumis- ja vaikuttamismahdollisuuksien järjestämisen takana:

”-- mutta jos sitä työtä mitä tuolla tehdään ei millään tavalla huomioida tai jos se on joku marginaalinen tai jos se on joku, jopa perustelu tehdä joku asia niin et, sillä ei oo tavallaan semmosta legitimiteettiä mut se yritetään hakee sitä kautta et tässä oli järjestöjä mukana tätä suunnittelemassa -- niin se on vaan tosi kurja juttu." (J9.)

Järjestöjen edustajat eivät siis suhtautuneet varauksettomasti hallinnon tarjoamiin mahdollisuuksiin osallistua uudistuksen valmistelutyöhön. Kokemus osallistumisen vaikuttavuudesta riippuikin merkittävästi siitä, miten osallistujien työpanos onnistuttiin tekemään näkyväksi päätöksentekovaiheessa.

Osallistumis- ja vaikuttamismahdollisuuksien uskottavuutta söi joidenkin haastateltavien silmissä lisäksi se, että järjestöjen toivottiin reagoivan uudistuksen etenemiseen lyhyellä varoitusajalla. Eräs haastateltavista viittasikin toimintaprosessien erirytmisyyteen, joka heikensi järjestöjen mahdollisuuksia valvoa oman kohderyhmänsä, kansalaisten ja järjestöjen itsensä etuja uudistuksen valmistelussa. Tältä osin valmistelutyössä mukanaolo aiheutti kriittisiä pohdintoja lumeryhmästä, jossa asiat käytiin teknisesti läpi ja asiakirjoihin kirjattiin tarvittavat merkinnät todellisten vaikutusten ollessa epäselviä. Kuten eräs haastateltavista totesi, uudistuksen kannalta isot kysymykset eivät välttämättä edes päätyneet valmisteluryhmän pohdittavaksi. Pääosin haastatellut olivat kuitenkin tyytyväisiä siihen, miten Pirkanmaan alueella järjestöt oli huomioitu uudistuksen valmistelutyössä, mutta niiden asema haluttiin turvata myös päätös- ja toteuttamisvaiheessa. Osa haastateltavista näkikin uudistuksen mahdollisuutena muuttaa päätöksenteon rakenteita ja vahvistaa järjestöedustajien asemaa "päättävissä pöydissä" - ei vain valmisteluvaiheessa vaan myös päätöksenteon hetkessä - ja tehdä valmistelua varten muodostetuista osallistumisen rakenteista pysyviä.

Haastattelu- ja kyselyaineiston perusteella on aiheellista pohtia lisäksi sitä, miten järjestö- 
jen rahoituspohja vaikuttaa niiden mahdollisuuksiin toimia kansalaisten edunvalvojina ja julkisen sektorin "laadunvalvojina". Monet haastateltavien edustamista järjestöistä olivat esimerkiksi riippuvaisia kaupungin avustuksista ja kaupungin tarjoamista ilmaisista tiloista. Tämä voi asettaa järjestöt hankalaan välikäteen tilanteessa, jossa järjestön ja rahoittajan toiveet eivät kohtaa. " [Haluaisin, että] virkamiehet kokevat järjestöt arvokkaina kumppaneina myös silloin, kun asioista ollaan eri mieltä. Nyt tilanne on se, että järjestöt ovat arvokkaita kumppaneita, kun ne toteuttavat sitä, mitä julkinen sektori haluaa niiden toteuttavan ja saavat rahoitusta sen mukaan. Kritiikkiä ei uskalleta tuoda esiin, sillä ruokkivaa kättä ei haluta purra", totesi eräs lomakekyselyyn vastanneista järjestötoimijoista.

Tilanne korostui muutaman haastateltavan mukaan niiden järjestöjen kohdalla, jotka toimivat palvelutuottajina:

"-- järjestöt on ollut perinteisesti se vallan vahtikoira joka on näissä tilanteissa älähtänyt ja sanonut, että nyt tää ei voi mennä näin, niin tällä hetkellä järjestöt on valjastettu sen vallan välineeksi sillä tavoin että niitten toiminta ja niitten rahoitus on riippuvaista siitä että se kunta ostaa niiltä edelleen sitä palvelua, ja toisaalta ne on itse tarjonneet sitä palvelua kunnalle rahaa vastaan toteutettavaksi ja ne on siinä tilanteessa et ne ei voi lähtee itse sitä kritisoimaan. -- tuntuu tavallaan et siellä on rahalla hiljennetty tiettyjä toimijoita kokonaan ja se on mun mielestä ihan hirvee tilanne. (J9.)

Haastateltavan mukaan palveluja tuottavat järjestöt eivät siis voi vapaasti kritisoida julkisen sektorin palveluita, koska ne tuottavat niistä osan itse - toisaalta järjestöjen toiminnan tulevaisuus riippuu siitä, ostaako julkinen sektori myös jatkossa järjestön tuottamia palveluita. Voidaankin pohtia, miten hyvin palvelutuottajan rooli sopii yhteen järjestön edunvalvontatehtävien kanssa.

Kaiken kaikkiaan haastatteluista nousi kuitenkin esille positiivinen suhtautuminen tulevaisuuteen ja järjestöjen vaikutusmahdollisuuksiin yhteiskunnassa. Järjestöjen välisiä eroja ei nähty vain ongelmana vaan valmistelutyön edustuk- sellisuutta lisäävänä rikkautena. Eri kohderyhmiä edustavat järjestöt pystyivät tuomaan esille tärkeitä huomioita esimerkiksi esteellisyyteen, selko- tai "kapulakielisyyteen" liittyen. Moni haastatelluista näkikin maakunta- ja sote-uudistuksen mahdollisuutena vaikuttaa syntyviin rakenteisiin ja vahvistaa kansalaisyhteiskunnan roolia palvelujen valmisteluvaiheessa kunta- ja makkuntatasolla. Kuten eräs kyselylomakkeeseen vastanneista totesi:

Toisaalta, jos ei oteta tätä kansalaisyhteiskuntaa tosissaan ja haltuun, me menetetään tää. Me ei sitten olla mukana aidosti ja oikeasti päätöksenteossa. Nyt on kansalaisyhteiskunnan paikka ja osallistumisen paikka ja siihen pitää tarttua. Ollaan vaan rohkeasti mukana ja vaaditaan kuuntelemisen paikkoja. Kun luottamusta syntyy, niin syntyy vuorovaikutusta ja vaikutuksia.

Haasteltavien mukaan maakunta- ja soteuudistuksen valmistelu on haastanut järjestökenttää myös hyvässä. Uudistus on pakottanut järjestöt kirkastamaan oman toimintansa ydintä ja viestimään siitä tehokkaammin ulospäin. Erään haastateltavan mukaan pirkanmaalaisissa järjestöissä on otettu kehitysaskeleita, joita ei olisi tapahtunut ilman uudistuksen synnyttämää ulkoista painetta. "Tää pakottaa -- uudistumaan ja perustelemaan ja tekemään yhteistyötä ja kaikkee tämmöstä. Valtavasti työtä, mut et tuli sotea tai ei ni kyllä mä koen et tässä asiat menee eteenpäin." (J3.) Uudistuksen valmistelu on siis ajanut järjestöjä tarkastelemaan omaa ja koko kentän toimintaa kriittisesti - ja tekemään yhteistyötä yli järjestörajojen: " -- järjestökenttien tulis tehdä paljon yhteistyötä --. Et semmonen pieni piipertäminen ei enää ehkä ole tämän vuosituhannen juttu." (J10.) Moni haastatelluista toi esiin sen, kuinka uudistuksen valmistelun myötä järjestöt olivat "tiivistäneet rivejään" lisääntyneen yhteistyön merkeissä. Yhteistyö ja yhtenäisempi ääni voivat lisätä koko kolmannen sektorin painoarvoa ja vahvistaa järjestöjen mahdollisuuksia edustaa kansalaisia onnistuneesti hallinnon uudistuksissa myös tulevaisuudessa. 


\section{TUTKIMUSTULOSTEN TULKINTA}

Tutkimuskysymyksemme tässä artikkelissa oli, millä tavoin järjestöt voivat edustaa kansalaisia hallinnonuudistuksen kontekstissa? Kuten teoreettisessa viitekehyksessä todettiin, hallintojärjestelmien legitimiteetti rakentuu - edustuksellisen järjestelmän lisäksi - kansalaisten ja erilaisten sidosryhmien osallistumisen kautta. Tästä näkökulmasta voidaan pohtia tutkimuskysymyksen muotoilua "millä tavoin järjestöt voivat edustaa..." erityisesti osallistumisen vaikuttavuuden suhteen. Tutkimuksessa nousikin esille kriittisiä huomioita siitä, mikä oli järjestöjen uudistustyöhön osallistamisen todellinen päämäärä: oliko tavoitteena prosessin legitimointi?

Kuten Peltonen (2002) toteaa, julkishallinnon organisaatiot työskentelevät mielellään toimijoiden kanssa, joiden toimintalogiikka muistuttaa niiden omaa toimintalogiikkaa. Tämä korostaa järjestöjen roolia asiantuntijoina. Järjestöiltä myös odotetaan ammattimaisuutta ja ammatillisten normien täyttämistä. Moni haastatelluista katsoi järjestöjen täyttävän asiantuntijaroolin luontevasti, sillä järjestöillä on esimerkiksi erityisryhmiin liittyvää erikoisosaamista. Asiantuntijuuden vaade vaikeutti kuitenkin monen haastateltavan mielestä paikallista vaikuttamistyötä ja edunvalvontaa, sillä järjestöjen paikallisyhdistysten jäsenet eivät aina kokeneet oman osaamistasonsa riittäväksi kunta- ja maakuntahallinnon edustajien kanssa toimimiseen. Haastateltavien kokemusta tukee Salmisen ym. $(2016,68)$ huomio siitä, kuinka monimutkaiset aiheet ja professionaalis-tekninen kieli vaikuttavat vuorovaikutukseen ja voivat ylläpitää toimijoiden välisiä hierarkioita.

Osa haastateltavista katsoi, että julkishallinnon toimijoilla ei ole kokonaiskuvaa järjestökentän toimintamahdollisuuksista ja potentiaalista. Tämä johtui osittain järjestökentän monimuotoisuudesta (esim. erot toimintalogiikassa, ammattimaisuuden asteessa ja rahoituspohjassa). Henkilökohtaisten, järjestöjen ja kuntasektorin välisten suhteiden avulla järjestöjen oli kuitenkin mahdollista tuoda esiin omaa potentiaaliaan ja toiminnan tuottamaa lisäarvoa yhteiskunnalle. Näiden kahdenvälisten suhteiden kuitenkin koettiin olevan vaarassa hallinnonuudistuksen myötä. Järjestökentän moninaisuuden tunnis- taminen ja yhteydenpitokanavien säilyttäminen muutoksessa onkin oleellista, jotta järjestöjen osaamista voidaan parhaalla tavalla hyödyntää sosiaali- ja terveyspalvelujen järjestämisessä hallituksen esityksen (HE 15/2017) hengen mukaisesti ${ }^{6}$. Toisaalta järjestöiltä voidaan edellyttää "oman toiminnan kirkastamista" ja siitä viestimistä tehokkaammin.

Legitimiteetin kannalta on olennaista, onko kyse päätöksenteko- vai prosessiosallistumisesta. Moni haastatelluista järjestöjen edustajista oli tyytyväinen siihen, miten järjestöt oli Pirkanmaalla otettu mukaan maakunta- ja soteuudistuksen valmisteluun. Uudistus myös nähtiin mahdollisuutena vahvistaa kansalaisyhteiskunnan roolia sosiaali- ja terveyspalvelujen valmisteluvaiheessa: järjestöille ikään kuin avautui ikkuna, jonka kautta kannanottoja voidaan syöttää rakentumisvaiheessa olevaan järjestelmään. Haastateltavat kuitenkin suhtautuivat kriittisesti siihen, miten järjestöjen osallistuminen uudistuksen valmisteluun ja kehittämistyöhön konkretisoitui päätöksenteossa. Uudistuvan hallintojärjestelmän legitimiteetin kannalta on ongelmallista, jos osallistumisen vaikutuksia ei pystyä osoittamaan konkreettisesti päätöksentekoprosessien lopputuloksissa. Vaikka hallintojärjestelmää pidettäisiin sen rakennusvaiheessa, eli menetelmällisesti, legitiiminä (syötepuoli), vaikuttaa tuotosvaihe eli päätösten arviointi myös luonnollisesti legitimiteetin rakentumiseen. (Jäntti ym. 2017; Vartiainen 2011.) Tehtyjen päätösten arvioiminen eli osallistumisprosessin arvioiminen sisällöllisesti on merkittävää erityisesti, kun järjestöjä tarkastellaan kansalaisyhteiskunnan edustajina: kansalaistoiminnassa ei pyritä vain mielipiteen ilmaisuun, vaan toiminnan tavoitteena on konkreettinen vaikuttaminen yhteiskuntaan (Anttiroiko ym. 2007, 252).

Michelsin (2011) mukaan osallistuminen vastuuttaa päätöksentekijöitä tehtyjen päätösten seurauksista ja luokin painetta hallinnolle myös huomioida ja toteuttaa osallistujien näkemykset, sekä viestiä valituista linjoista ja niiden perusteista. Joskus tie kuitenkin nousee pystyyn: esimerkiksi silloin kun kehittäjillä ei ole oman toimenkuvansa puolesta mahdollisuuksia tai resursseja toteuttaa kuntalaisten ideoimia kehityskohteita (ks. esim. Tuurnas 2016b). Sama havainto nousee esille monista osallistumista käsittelevistä tutkimuksista. Julkisella hallinnolla 
tulisikin olla myös hallinnollista tilaa viedä osallistujien esityksiä eteenpäin. Tämä korostuu esimerkiksi kunnan ja valtion suhteessa - miten ja missä määrin valtio lopulta ohjaa eritasoisia suunnittelun prosesseja (Kanninen ja Bäcklund, 2017). Maakunta- ja soteuudistuksessa paikallista valmistelutyötä tekevät instanssit ovatkin olleet riippuvaisia valtakunnan politiikasta ja muuttuvista suunnista.

Tutkimuksessamme nousi esille myös uudistuksen valmisteluprosessien erirytmisyys - kuten asia aineistossa ilmaistiin - suhteessa järjestökentän tapaan toimia. Osa esityksistä ja ehdotuksista tuotiin kommentoitavaksi lyhyellä aikataululla, mikä vaikutti siihen, miten vaikuttavia ja loppuun mietittyjä kantoja kansalaisyhteiskunnan edustajat pystyivät tuottamaan. Myös julkishallinnon erilaiset toimintalogiikat ja päätöksenteon prosessit nousivat aineistosta esille esteenä vaikuttavalle osallistumiselle järjestöjen näkökulmasta. Tähän liittyy kysymys siitä, miten osallistuminen suunnitellaan. Järjestöjen asiantuntemuksesta saa parhaan hyödyn, kun ne pääsevät nostamaan esiin omien kohderyhmiensä asioita hallinnon prosessien kehittämisen sijaan. Osallistumisen vaikuttavuuden ongelma voidaan ymmärtää Edelenbosin (2005) huomion kautta: osallistuminen ei välttämättä ole linjassa olemassa olevan hallintojärjestelmän kanssa, jonka toimintalogiikka perustuu edustuksellisen demokratian vertikaaliseen vastuun ja vallan jakoon. Kuten teoreettisessa viitekehyksessä kuvasimme, osallistuminen voi näin aiheuttaa institutionaalista jännitettä.

\section{JOHTOPÄÄTÖKSET}

Kuten alussa totesimme, legitimiteettikysymysten lisäksi julkinen hallinto tarvitsee erilaisten sidosryhmien asiantuntijuutta sekä kokemukseen perustavaa tietoa yhteiskunnallisten ongelmien ratkaisemiseksi (ks. esim. Innes \& Booher 2010; Ansell \& Gash 2008). Tässä tutkimuksessa korostuu erityisesti sosiaali- ja terveysalan järjestöjen asiantuntijuuden hyödyntäminen hallinnonuudistuksessa. Voidaankin todeta, että monia erilaisia viiteryhmiä edustavien järjestöjen asiantuntemuksen avulla julkisen hallinnon edustajien on mahdollista saada ymmärrystä ja tietoa erilaisten kuntalaisten tarpeista ja mahdollisuuksista vaikuttaa omiin palveluihinsa.
Järjestöt voivatkin toimia kansalaisten edustajina juuri tästä näkökulmasta: tuoden erilaisten ihmisten näkökulmaa kehittämistyöhön. Näin järjestöt toteuttavat Harjun $(2010,113)$ kuvailemaa roolia välittävänä aktorina kehittyvässä osallistuvassa demokratiassa, välittäen julkiselle hallinnolle kansalaisten ääntä muutosprosesseissa. Tutkimustuloksista nousee esille erityisesti kolme päähuomiota.

Ensinnäkin tutkimuksessa nousi esille neuvotteluaseman merkitys osallistumisprosesseissa. Hallintojärjestelmän ja kansalaisyhteiskunnan välinen kumppanuus ja verkostomainen yhteistyö edellyttävät vallan jakautumista ja sitä, että asioista neuvotellaan. Kummallakin osapuolella tulee olla mahdollisuus neuvotella päätöksenteon lopputuloksista ja toisaalta vetäytyä yhteistyöstä, jos sitä ei koeta mielekkääksi (Roberts 2000; Sørensen \& Torfing 2007). Kuten Arnstein $(1969,221)$ toteaa artikkelissaan, hallinnon ja kansalaisten välinen kumppanuus toteutuu parhaiten tilanteessa, jossa kansalaiset ja yhteisöt ovat järjestäytyneitä ja muodostavat jonkinasteisen "vallan pesäkkeen", joka on toimistaan vastuussa yhteisön muille jäsenille. Järjestäytyneisyys ja omavaraisuus edistävät tasa-arvoisemman neuvotteluaseman syntymistä, joka taas vahvistaa kansalaisten tasaveroiseen kumppanuuteen perustuvaa vuorovaikutusta suhteessa hallintojärjestelmään. Järjestöillä voi olla myös organisatorisen rakenteensa johdosta enemmän neuvotteluvaltaa esimerkiksi yksittäisiin kansalaisiin nähden, sillä osallistuminen tasaveroisena kehittäjäkumppanina julkisen hallinnon prosesseihin voi sisältää tietynasteisen asiantuntijuuden vaateen. (ks. esim. Peltonen 2002; Puustinen 2002).

Huomionarvoista on myös tuoda esille tuoreempi näkemys osallistumisen merkityksestä, jossa osallistuminen voidaan nähdä tapana oppia ja tuottaa ymmärrystä, ei vain lineaarisella arvoasteikolla mitattavaksi kamppailuksi yhteiskunnallisesta vallasta. Osallistumisen kautta tapahtuu yhteisöllistä oppimista, jota voidaan pitää edellytyksenä esimerkiksi ilmastonmuutoksen kaltaisiin yhteiskunnallisiin muutoksiin sopeutumisessa. (Collins \& Ison 2009). Kuitenkin uskomme, että valtakysymys on aina läsnä, kun puhutaan monia erilaisia näkemyksiä sisältävistä politiikkaprosesseista ja niihin osallistumisesta. 
Oma kysymyksensä on se, millä tavoin kansalaiset kokevat järjestöjen edustavan itseään. Tätä tutkimuksessa haastatellut järjestöjen edustajat pohtivat myös itse: kuten eräs haastateltavista totesi, järjestöissä on erikoistuttu järjestövaikuttamiseen vapaan kansalaisvaikuttamisen jäädessä taka-alalle. Tutkimuksemme tulokset neuvotteluaseman merkityksestä liittyvät myös keskusteluun yksittäisten kansalaisten osallistumisesta hallinnon kehittämiseen esimerkiksi kokemusasiantuntijoina (usein järjestöjen kautta toimivina), jolloin kysymys valta-asymmetriasta korostuu. Tutkimuksessamme järjestöt kokivat erityisesti paikallisen vaikuttamisen haastavaksi, sillä paikallistason toimijoilla ei välttämättä ollut hallinnon prosesseihin osallistumiseen tarvittavaa osaamista ja asiantuntijuutta. Samaan tapaan esimerkiksi Meriluoto (2016) osoittaa kokemusasiantuntijuuden ongelmakohtia legitimiteettikysymysten osalta.

Järjestöjen muodostaessa heterogeenisen toimijajoukon on tärkeää huomioida myös järjestöjen keskinäiset voimasuhteet. Hallinnan verkostoissa työskentelevien toimijoiden väliset valtasuhteet ovat harvoin symmetrisiä, sillä verkostotyöskentely ei tapahdu tyhjiössä: vallitsevat yhteiskunnalliset olosuhteet vaikuttavat vallan jakautumiseen verkoston jäsenten välillä (O’Toole 1997; Innes \& Booher 2010). Kuten tutkimuksemme tuloksista kävi ilmi, järjestöillä on keskenään erilaiset mahdollisuudet tuoda oman viiteryhmänsä asioita esille ja vaikuttaa niihin. Heterogeenisyys voikin muodostua ongelmaksi, jos isoille toimijoille, jotka ovat taloudellisesti vähemmän riippuvaisia esimerkiksi kunnista, muodostuu enemmän mahdollisuuksia etujensa ajamiseen. Tällöin voi syntyä tilanne, jossa tietyn ryhmän asiat pääsevät enemmän esille toisen ryhmän kustannuksella.

Kuitenkin, kuten edellä on todettu, järjestöt voivat parhaimmillaan toimia vahvoina vaikuttajina hallinnonuudistuksissa kansalaisten edustajina juuri silloin, kun niissä on joukkovoimaa. Yhteistyötä tehden ne voivat tuoda moniäänisesti vanhusten, nuorten, vammaisten, maahanmuuttajien, syrjäytyneiden tai vaikkapa erilaisten potilasryhmien näkökulmia hallinnon kehittämiseen ja uudistustyöhön. Usein järjestöjen edustamat kohderyhmät ovatkin sellaisia, joiden osallistumista julkisen hallinnon osalta pidetään tärkeänä, mutta vaikeasti toteutettava- na. Kuten tutkimuksessamme nousi esille, juuri yhteistyö nähtiin järjestöjen tulevaisuuden kannalta haasteellisena mutta myös tavoiteltavan asiana.

Lopuksi, huolimatta hallinnonuudistuksen luomista, epävarmuutta herättävistä tulevaisuudenkuvista, järjestöissä suhtauduttiin pääosin positiivisesti tulevaisuuteen. Kuten eräs haastateltava totesi: "Jotenkin ite näkee kuitenkin niin kirkkaana sen järjestöjen roolin sitten kuitenkin Suomessa ja suomalaisessa yhteiskunnassa, et juuret on niin syvällä mullassa et ei meistä ihan heti eroon pääse ainakaan. Mut avoimin mielin, kohti tulevaa." (J4.)

\section{VIITTEET}

1 Maakunta- ja soteuudistus luo artikkelissamme kontekstin erityisesti hallinnon uudistamisen näkökulmasta, eikä tutkimus ole näin ollen sidottu uudistamisprosessin lopputulokseen.

2 Katso myös Bäcklund 2007.

3 Tässä artikkelissa emme kuitenkaan arvioi tätä kehitystä, vaan keskitymme tarkastelemaan järjestöjen odotuksia ja näkemyksiä omasta roolistaan hallinnon uudistamisen kontekstissa.

4 Vaihtoehtojen ollessa intristinen tapaustutkimus [intrinsic case study] tai kollektiivinen tapaustutkimus [collective case study] (Stake 1995).

5 STEA:n toiminta rahoitetaan Veikkaus Oy:n pelituotoilla.

6 Maakuntalain tavoitteena on "luoda edellytykset maakuntien ja järjestöjen väliselle yhteistyölle ja järjestöjen vaikutusmahdollisuuksille”. Järjestöjen osaaminen tulisi huomioida mahdollisimman varhaisessa vaiheessa palveluiden suunnittelua. (HE 15/2017; STM 2018.)

\section{LÄHTEET}

Airaksinen, Jenni (2009). Hankala hallintouudistus. Väitöskirja. Acta Universitatis Tamperensis 1397. Tampere: Tampere University Press.

Ansell, Chris \& Alison Gash (2008). Collaborative governance in theory and practice. Journal of public administration research and theory, 18(4): 543-571.

Anttonen, Anneli, Liisa Häikiö \& Heli Valokivi (2012). Vastuu, valinta ja osallistuminen sosiaalipalveluissa: Vanhushoivapolitiikan muutos 
ja arkinen hoivavastuu. Teoksessa Anttonen, Anneli, Arto Haveri, Juhani Lehto \& Hannele Palukka (toim.), Yksityisen ja julkisen rajapinnoilla: Julkisen palvelun muutos, Tampere: Tampere University Press, 19-46.

Anttiroiko, Ari-Veikko, Arto Haveri, Veli Karhu, Aimo Ryynänen \& Pentti Siitonen (2007). Kuntien toiminta, johtaminen ja hallintasuhteet. Tampere: Tampere University Press.

Arnstein, Sherry R. (1969). A ladder of citizen participation. Journal of the American Institute of planners, 35(4): 216-224.

Baiocchi, Gianpaolo (2001). Participation, activism, and politics: The Porto Alegre experiment and deliberative democratic theory. Politics \& Society, 29(1): 43-72.

Brandsen, Taco, Willem Trommel \& Bram Verschuere (2017). The State and reconstruction of civil society. International Review of Administrative Sciences, 83(4): 676-693.

Botero, Andrea, Andrew Paterson \& Joanna SaadSulonen (2012). Towards peer production in public services: Cases from Finland. Helsinki: Aalto University.

Collins, Kevin \& Ray Ison (2009). Jumping off Arnstein's ladder: social learning as a new policy paradigm for climate change adaptation. Environmental Policy and Governance, 19(6): 358-373.

Dryzek, John (2005). Deliberative Democracy in Divided Societies: Alternatives to Agonism and Analgesia”. Political Theory, 33(2): 218-242.

Edelenbos, Jurian (2005). Institutional implications of interactive governance: Insights from Dutch practice. Governance, 18(1): 111-134.

Evers, Adalbert (2005). Mixed welfare systems and hybrid organizations: Changes in the governance and provision of social services. International Journal of Public Administration, 28: 737-748.

Evers, Adalbert \& Jean-Louis Laville (2004). Defining the third sector in Europe. Teoksessa Evers, Adalbert \& Jean-Louis Laville (toim.), The Third Sector in Europe, Cheltenham: Edward Elgar Publishing.

Flyvbjerg, Bent (2006). Five misunderstandings about case-study research. Qualitative Inquiry, 12(2): 219-245.

Fotaki, Marianna (2011). Toward developing new partnerships in public services: Users as consumers, citizens and/or co-producers in health and social care in England and Sweden. Public Administration, 89(3): 933-955.

Giugni, Marco G. \& Florence Passy (1998). Contentious Politics in Complex Societies: New Social Movements between Conflict and
Cooperation. Teoksessa Giugni, Marco G., Doug McAdam \& Charles Tilly (toim.), From Contention to Democracy, Lanham: Rowman \& Littlefield, 81-108.

Gläser, Jochen \& Grit Laudel (2013). Life with and without coding: Two methods for early-stage data analysis in qualitative research aiming at causal explanations. Forum Qualitative Sozialforschung / Forum: Qualitative Social Research, 14(2).

Greve, Carsten (2015). Ideas in public management reform for the 2010s: Digitalization, value creation and involvement. Public Organization Review, 15(1): 49-65.

Harju, Aaro (2010). Puheenvuoro kansalaisyhteiskunnan tulevaisuudesta. Helsinki: Sivistysliitto Kansalaisfoorumi.

Haveri, Arto (2012). Towards city region-wide corporate local authorities? Reflections on new urban governance in Finland. Paper presented at The EU Strategy for the Baltic Sea Region 15.11.2012.

Haveri, Arto \& Majoinen, Kaija (2017). Miten tähän on tultu? Kunnallishallinnon muutos polkuriippuvana ja evolutionäärisenä kehityksenä. Teoksessa Nyholm Inga, Haveri Arto, Majoinen Kaija \& Pekola-Sjöblom Marianne (Toim.) Tulevaisuuden kunta, ACTA 264, Suomen kuntaliitto, Tampereen yliopisto ja Valtiovarainministeriö, Helsinki, 42-55.

HE 15/2017 (2017). Hallituksen esitys eduskunnalle maakuntien perustamista ja sosiaali- ja terveydenhuollon järjestämisen uudistusta koskevaksi lainsäädännöksi sekä Euroopan paikallisen itsehallinnon peruskirjan 12 ja 13 artiklan mukaisen ilmoituksen antamiseksi. Annettu 2.3.2017. Haettu osoitteesta https://www.finlex.fi/fi/esitykset/he/2017/20170015, luettu 15.4.2019.

Härkönen, Helena, Inga Nyholm, Arto Haveri \& Jenni Airaksinen (2015). "Legitimaation lähteet metropolirakenteissa." Teoksessa Karppi, Ilari (toim.), Hallinnan uusia ulottuvuuksia, Tampereen yliopisto, Johtamiskorkeakoulu, 188-214.

Innes, Judith E. \& David E. Booher (2010). Planning with complexity: An introduction to collaborative rationality for public policy. Abingdon-onThames: Routledge.

Julkunen, Raija (2006). Kuka vastaa? Hyvinvointivaltion rajat ja julkinen vastuu. Helsinki: Stakes.

Jupp, Victor (2006). Purposive sampling: The SAGE dictionary of social research methods. Sage.

Jäntti, Anni, Jenni Airaksinen \& Arto Haveri (2017). Osallistuminen julkishallinnon legi- 
timiteettikysymyksenä. Teoksessa Bäcklund, Pia, Jouni Häkli \& Harry Schulman (toim.), Kansalaiset kaupunkia kehittämässä, Tampere: Tampere University Press, 34-56.

Kanninen, Vesa \& Pia Bäcklund (2017). Kansalaisosallistumisen institutionaaliset rajat? Teoksessa Bäcklund, Pia, Jouni Häkli \& Harry Schulman (toim.), Kansalaiset kaupunkia kehittämässä, Tampere: Tampere University Press, 16-33.

Kansalaisyhteiskuntapolitiikan neuvottelukunta, Kansalaisareena ry ja Suomen kuntaliitto (2015). Kuntakysely yhteistyöstä kolmannen sektorin kanssa. Saatavissa http://kansalaisareena. fi/kuntakysely.pdf, luettu 25.4.2018.

Klijn, Erik-Hans \& Jurian Edelenbos (2013). The Influence of Democratic Legitimacy on Outcomes in Governance Networks. Administration and Society, 45(6): 627-650.

Klijn, Erik-Hans \& Joop F. M. Koppenjan (2012). Governance network theory: past, present and future. Policy \& Politics, 40(4): 587-606.

Klijn, Erik-Hans \& Chris Skelcher (2007). Democracy and governance networks: compatible or not? Public administration, 85(3): 587-608.

Koskiaho, Briitta (2015). Tehdään enemmän vähemmällä. Kansalainen ja kansalaisyhteiskunta sosiaalipolitiikan voimavarana. Yhteiskuntapolitiikka, 80(1): 54-63.

Meriluoto, Taina (2016). Kokemusasiantuntijuus ohjaavana ja voimaannuttavana toimintana. Teoksessa Nousiainen, Marko \& Kari Kulovaara (toim.), Hallinnan ja osallistamisen politiikat, Jyväskylä: Jyväskylän yliopisto, 65-96.

Michels, Ank (2011). Innovations in democratic governance: how does citizen participation contribute to a better democracy? International Review of Administrative Sciences, 77(2): 275293.

Mäkinen, Kaisa (2016). Osallistuminen lähentämisen ja yhteisönrakentamisen väylänä EU:n kansalaisuuspolitiikassa. Teoksessa Kuokkanen, Kanerva, Taina Meriluoto \& Kaisa Mäkinen (toim.), Hallinnan ja osallistamisen politiikat, Jyväskylä: Jyväskylän yliopisto, 97-124.

Osborne, Stephen P. (2010). The (new) public governance: A suitable case for treatment? Introduction. Teoksessa Osborne, Stephen (toim.), The new public governance? Emerging perspectives on the theory and practice of public governance, Abingdon, Oxon: Routledge, 1-16.

O’Toole Jr, Laurence J. (1997). Treating networks seriously: Practical and research-based agendas in public administration. Public administration review, 57(1): 45-52.
Peeters, Rik (2013). Responsibilisation on Governement's Terms: New Welfare and the Governance of Responsibility and Solidarity. Social Policy and Society, 12(4): 583-595.

Peltonen, Lassi (2002). " Sotkuinen demokratia" ja Tampere-foorumi: talkootoimintaa julkisen tilan puolesta. Kunnallistieteellinen aikakauskirja, 30(2): 168-183.

Peltosalmi, Juha, Tyyne Hakkarainen, Riitta Särkelä \& Anne Eronen (2012). Järjestöbarometri 2012. Helsinki: SOSTE.

Pestoff, Victor (2012). Co-production and Third Sector Social Services in Europe: Some Concepts and Evidence. Voluntas: International Journal of Voluntary and Nonprofit Organizations, 23(4): 1102-1118.

Pestoff, Victor (2012b). New Public Governance, Co-production and the Third Sector Social Services in Europe: Crowding In and Crowding Out. Teoksessa Pestoff, Victor, Taco Brandsen \& Bram Verschuere (toim.), New Public Governance, the Third Sector and Co-Production, New York: Routledge, 361-380.

Pirkanmaa 2019 (2017). Pirkanmaa2019 loppuraportti: Osallistuminen - teemaryhmä. Saatavissa http://www.pirkanmaa.fi/wp-content/uploads/07_Osallistuminen_loppuraportti.pdf, luettu 2.10.2018.

Puustinen, Sari (2002). Suunnittelijat yleisen edun takaajina? Teoksessa Pia Bäcklund, Jouni Häkli \& Harry Schulman (toim.), Osalliset ja osaajat. Kansalaiset kaupungin suunnittelussa, Helsinki: Gaudeamus, 218-242.

Rittel, Horst W. \& Melvin M. Webber (1973). Dilemmas in a general theory of planning. Policy sciences, 4(2): 155-169.

Roberts, Nancy (2000). Wicked problems and network approaches to resolution. International public management review, 1(1): 1-19.

Salminen, Jarkko, Liisa Häikiö \& Pauliina Lehtonen (2016). Osallistuva budjetointi hallinnollisena ja poliittisena käytäntönä. Hallinnon tutkimus, 35(1): 60-75.

Schmitter, Philippe (2001). What is there to legitimize in the European Union... and how might this be accomplished? IHS Political Science Series.

Schreier, Margrit (2014). Qualitative Content Analysis. Teoksessa Flick, Uwe (toim.), The SAGE Handbook of Qualitative Data Analysis, London: SAGE Publications Ltd, 170-184.

Siisiäinen, Martti \& Tomi Kankainen (2009). Järjestötoiminnan kehitys ja tulevaisuudennäkymät Suomessa. Teoksessa Kankainen, Tomi, Heli Pessala, Martti Siisiäinen, Leo Stranius, Hanna Wass \& Niklas Wilhelmsson (toim.), 
Suomalaiset osallistujina. Katsaus suomalaisen kansalaisvaikuttamisen tilaan ja tutkimukseen. Oikeusministeriön julkaisu 2009:5, Helsinki: Edita, 90-137.

Sjöblom, Stefan (2011). Finland: The limits of the unitary decentralized model. Teoksessa Loughlin, John, Frank Hendriks \& Anders Lidström (toim.), The Oxford handbook of local and regional democracy in Europe, Oxford: Oxford University Press, 241-260.

Smolej, Mirka (2017). Vapaaehtoistyöstä palveluntuotantoon - kasvava ammatillisuuden vaatimus kolmannen sektorin lastensuojelujärjestö Suomen Icehearts Ry:ssä. Janus Sosiaalipolitiikan ja sosiaalityön tutkimuksen aikakauslehti, 25(1): 4-20.

Sosiaali- ja terveysministeriö (2018). Järjestöjen rooli maakunta- ja soteuudistuksessa. Sosiaalija terveysministeriön raportteja ja muistioita 26/2018. Helsinki: Sosiaali- ja terveysministeriö.

SOSTE (2016). Järjestöbarometri: Järjestö-kuntayhteistyö toimivaksi. Saatavissa https://www. soste.fi/media/jarjestobarometri-2016-soste-suosittelee-jarjesto-kuntayhteistyo-toimivaksi.pdf, luettu 25.4.2018.

Sotarauta, Markku (1998). Kohti epäselvyyden hallintaa: Pehmeä strategia 2000-luvun alun suunnittelun lähtökohtana. Tampere: Tampere University Press.

Särkelä, Riitta (2016). Järjestöt julkisen kumppanista markkinoiden puristukseen: Sosiaali- ja terveysjärjestöjen muutos sosiaalipalvelujen tuottajana vuosina 1990-2010. Helsinki: Ensija turvakotien liitto ja Lapin yliopiston yhteiskuntatieteiden tiedekunta.

Sørensen, Eva \& Jacob Torfing (2007). Introduction governance network research: Towards a second generation. Teoksessa Sørensen, Eva \& Jacob Torfing (toim.), Theories of democratic network governance, Lontoo: Palgrave Macmillan, 1-21.

Sørensen, Eva \& Jacob Torfing (2012). Introduction: Collaborative Innovation in the Public Sector. The Innovation Journal: The Public Sector Innovation Journal, 17(1): 1-14.

Tuurnas, Sanna (2016). The Professional Side of Co-Production. Väitöskirja. Acta Universitatis Tamperensis 2163. Tampere: Tampere University Press.

Tuurnas, Sanna (2016b). Looking beyond the simplistic ideals of participatory projects: Fostering effective co-production. International Journal of Public Administration, 39(13): 1077-1087.

Valtiovarainministeriö (2017). Tulevaisuuden kunnan skenaariot ja visiot 2030. Parlamentaarisen työryhmän väliraportti Tulevaisuuden kunnasta. Helsinki: Valtiovarainministeriön julkaisuja 9a/2017.

Vartiainen, Pirkko (2011). Osallistumisen oikeutus: deliberatiivisen demokratian legitiimit piirteet. Teoksessa Hyyryläinen, Esa \& Olli-Pekka Viinamäki (toim.), Julkinen hallinto ja julkinen johtaminen: juhlakirja professori Ari Salmisen 60-vuotispäivän kunniaksi, Vaasa: Vaasan yliopisto, 54-63.

Voorberg, William H., Viktor J.J.M. Bekkers \& Lars G. Tummers (2014). A systematic review of co-creation and co-production: Embarking on the social innovation journey. Public Management Review, 17(9): 1333-1357.

Yin, Robert K. (1993). Applications of case study research. Beverly Hills, CA: SAGE Publishers. 